University of Windsor

Scholarship at UWindsor

$11-2017$

\title{
Digital Locks, Physical Objects and Immaterial Works
}

\author{
Pascale Chapdelaine
}

University of WIndsor

Follow this and additional works at: https://scholar.uwindsor.ca/lawpub

Part of the Law Commons

\section{Recommended Citation}

Chapdelaine, Pascale. (2017). Digital Locks, Physical Objects and Immaterial Works. Copyright User Rights: Contracts and the Erosion of Property, 129-149.

https://scholar.uwindsor.ca/lawpub/57

This Contribution to Book is brought to you for free and open access by the Faculty of Law at Scholarship at UWindsor. It has been accepted for inclusion in Law Publications by an authorized administrator of Scholarship at UWindsor. For more information, please contact scholarship@uwindsor.ca. 


\title{
Copyright User Rights
}

Contracts and the Erosion of Property

\author{
PASCALE CHAPDELAINE \\ $B C L, L L B, L L M, P h D$ \\ Acsociate Professor, University of Windsor, Faculty of Laws, \\ of the Bar of Ontario and le Barreasu du Quebec
}




\section{6 \\ Digital Locks, Physical Objects, and Immaterial Works}

\section{A Paradigm Shift for Digital Copyright Users}

One of the greatest controversies in contemporary copyright law is the legal protection afforded to digital locks, those technological measures that restrain users' powers and privileges in e-books, musical recordings, films, computer software, and, increasingly, other objects the main purpose of which is not to embody copyright works, for example, cars, and farming equipment. ${ }^{1}$ The controversy concerns the introduction of technological protection measures (TPMs) by the WIPO Internet treaties of $1996,{ }^{2}$ their necessity, and the required level of implementation by member states. ${ }^{3}$ As quickly as TPMs solidified copyright holders' rights to digital works, their introduction undermined arguments for the existence of copyright user rights in general and digital copyright user rights in particular. ${ }^{4}$ By creating a separate parallel regime for digital copyright works, TPMs shifted the paradigm by redefining the rules of engagement as to how users would increasingly access and experience copyright works.

Technological measures and their protection through TPMs impact copyright holders' intangible property rights by augmenting them, as much as they constrain the scope of copyright users' tangible personal property powers and privileges in the copies they protect. ${ }^{5}$ Copyright holders apply technological measures to copies

\footnotetext{
1 Branislav Hazucha, Hsiao-Chien Liu, \& Toshihide Warabe, 'Copyright, Technological Protection Measures and Their Acceptance by Consumers in Japan' (2013), SERCI, at 6-10, online: <http:// www.serci.org/2013/Hazucha-SERCI-2013.pdf accessed 4 February 2017, providing an overview of various technological measures applied to different types of copyright works.

2 WIPO Copyright Treaty, 20 December 1996, WO033EN, art 11, online: chttp://www.wipo. int/treaties/en/ip/wct/trtdocs_wo033.html\#P8_189> accessed 4 February 2017 [WCT]; WTPO Performances and Phonograms Treath 20 December 1996, WO034EN, art 18, online: <htp://www. wipo.int/treaties/en/ip/wppt/trtdocs_wo034.html> accessed 4 February 2017 [WPPT].

${ }^{3}$ For a Canadian perspective on the digital agenda of the WTPO Internet treaties, and particularly the 'TPM provisions, see Michael Geist, ed, From 'Radical Extremism' to 'Balanced Copyright': Canadian Copyright and the Digital Agenda (Totonto: Irwin Law, 2010), in particular ch 7: Carys Craig, 'Locking Out Lawful Users: Fair Dealing and Anti-Circumvention in Bill C-32' and ch 8: Michael Geist, 'The Case for Flexibility in Implementing the WIPO Internet Treaties: An Examination of the AntiCircumvention Requirements.' [Geist, "The Case for Flexibility'].

I See Chapter 2: 'User rights or privileges?"

3 See below: "Technological protection measures and the search for balance in copyright law.'
} 
of copyright works, whether embodied in a physical object, whether distribured online, ${ }^{6}$ and whether users experience the copyright work through an individual copy they control or as a service. ${ }^{7}$ The legal protection of copyright holders' technological measures through TPMs is arguably the sharpest illustration of the trivialization of copyright users' property rights in copies of copyright works, ${ }^{8}$ and of exceptions to copyright infringement. ${ }^{9}$ In the case of TPMs, courts and legislators' struggles toward the coherent treatment of copies of copyright works with and without a physical embodiment, identified in Chapters 4 and 5 are still present, ${ }^{10}$ while there is another layer of complexity added to the difficulty to deal with the tangible and intangible dichotomy. The increased presence of digital locks in physical objects, the primary function of which is not to embody copyright works (e.g., cars, coffee makers), magnifies the regulatory design shortcomings that were identified at the outset of the introduction of TPMs more than two decades ago.

This chapter delves further into the tangible and intangible divide by looking at the effect of TPMs on a larger pool of users than traditional copyright users: that is, those inadvertent copyright users who buy a car or a tractor without suspecting that it embeds copyright works (e.g., software), let alone digital locks blocking access and use to important components of the physical object. In parallel, this chapter explores the changing role of TPMs in light of the shift from accessing copyright works through individualized digital copies to experiencing works through services.

\section{Technological Protection Measures and the Search for Balance in Copyright Law}

\section{International obligations}

The controversy around TPMs forms part of the broader debate about the proper balance that needs to subsist between the exclusive rights of copyright holders, the rights of copyright users, and the broader public interest. ${ }^{11}$ The WTPO Internet treaties' obligation to protect technological measures is one of the outcomes of the digital agenda put forward by the World Intellectual Property Organization (WIPO) that sought to address 'the profound impact of the development and convergence of information and communication technologies on the creation and use of literary and artistic works.' 12

6 ibid. 7 ibid. $\quad$ See Chapter 1.

9 See Chapter 2: "User rights or privileges?"; see below: "Technological protection measures and the search for balance in copyright law.'

10 See below: 'Technological protection measures and the search for balance in copyright law.'

11 For an overview of the policy and legal debate around TPMs from the perspective of copyright holders and copyright users and the public interest, and about where the proper balance should be struck, see Peter K Yu, 'Anticireumvention and Anti-Anticircumvention' (2006) 84 Denv UL Rev 13, in particular at $17-19$.

${ }_{12}$ WCT (n 2) Preamble. For a discussion of the new international obligations brought on by the WTPO Internet treaties in relation to TPMs and digital rights management, and of the drafting process 
The WIPO Internet treaties require member states to provide 'adequate legal protection and effective legal remedies against the circumvention of effective technological measures' used by copyright holders in relation to digital works, ${ }^{13}$ Questions about the minimum level of protection of technological measures that needs to be put in place to comply with the WIPO Internet treaties remain controversial and pertinent more than 20 years after the signature of the treaties as evidenced by national jurisdictions' efforts to implement the treaties in their domestic sphere. ${ }^{14}$ For instance, is there an obligation to prohibit the trafficking of circumventing devices or services, of technological measures (the WTPO Internet treaties being silent on that question), or should the prohibition be limited to the circumvention of technological measures? ${ }^{15}$ Does the copyright doctrine of contributory infringement or authorization, or general legal regimes of tort, contracts, criminal law provide adequate legal protection and effective legal remedies under the WTIPO Internet treaties or is there a need to implement specific TPM provisions? ${ }^{16}$

Regional treaties implementing the WIPO Internet treaties and subsequent international agreements have been more explicit (and arguably have gone further) than the WIPO Internet treaties on the scope of obligations of TPMs. ${ }^{17}$ Independently of the required level of protection of technological measures under the WIPO Internet treaties, other factors, including bilateral and regional trade agreements and political pressures by influential trading partners, have

leading up to their adoption, see Mihaly Fiesor, The Law of Copyright and the Intemet. The 1996 WTPO Treaties, Their Interpretation and Implementation (Oxford: Oxford University Press, 2002) Part III; Sam Ricketson \& Jane C Ginsburg, International Copyright and Neighbouring Rights, The Berne Convention and Beyond, 2nd ed (Oxford: Oxford University Press, 2006) at 964ff.

13 WCT (n 2) art 11; WPPT (n 2) art 18.

14 This is illustrated by Canada's various attempts at copyright legislative reform that finally led to the entry into force of the Copyright Modemization Act, SC 2012, c 20 in 2012. TPMs occupled the larger part of the debates throughout this copyright legislative reform. For earlier critiques of TPMs, see Pamela Samuelson, 'Intellectual Property and the Digital Economy: Why the AntiCircumvention Regulations Need to Be Revised' (1999) 14 BTLJ 519 at 534-43; David Nimmer, 'A Riff on Fair Use in the Digital Millennium Copytight Act' (2000) 148 U Pa L Rev 673; P Berne Hugenholtz, 'Why the Copyright Directive is Unimportant, and Possibly Invalid' (2000) 22 Eur IP Rev 499 at $499-501$.

15 For different views on that question, see: Geist, "The Case for Flexibility' (n 3), and Mihaly Ficsor, "TPMs and Flexibility ("The Ability of Bending without Breaking")-Why Should the TPM Provisions of Bill C-32 Protect Access Controls and Prohibit "Preparatory Acts", online: Osgoode Intellectual Property Law \& Technology Program <http:/www.iposgoode.ca/2010/11/digimal-lockscircumvention-and-the-copyright-reforms-proposed-by-bill-c-32/> accessed 4 February 2017.

16 Samuelson (n 14) at 530-34; Séverine Dusollier, "Situating Legal Protections for CopyrightRelared Technological Measures in the Broader Legal Landscape: Anti-Circumvention Protection Outside Copyright' in JC Ginsburg \& JM Besek, eds, Adjuncts and Alternatives to Copyright: Rroceedings of the ALAI Congress, June 13-17, 2001, New York, U.S.A. (New York: ALAI-USA, 2002) at 123.

17 EC, Directive 2001/29/EC of the European Parliament and of the Council of $22 \mathrm{May} 2001$ on the harmonisation of certain aspects of copyright and relased righs in the information society. [2001] O], L 167/10 [Directive 2001/29/EC]: art 6.2 requires its Member States to put in place an antitrafficking prohibition against TPM circumvention devices. Trans-Pacific Partnership, 4 February 2016, online: <htp://www.international.gc.ca/trade-agreements-accords-commerciaux/agr-acc/tpp$\mathrm{ptp} /$ text-texte/toc-tdm.aspx?'lang=eng> accessed 4 February 2017 [TPP]: art 18.68(1)(b) imposes obligations similar to those in Directive $2001 / 29 / E C$, and uses similar langtage. 
played a role in the level of protection of technological measures adopted by some member states. ${ }^{18}$

The WIPO Internet treaties in their purpose and design seek to secure greater protection for copyright holders. As special agreements of the Berne Convention for the Protection of Literary and Artistic Works [Berne Convention], ${ }^{19}$ the WIPO Internet treaties must increase the legal protection conferred on copyright holders or, at a minimum, contain no provisions that are contrary to the Berne Convention. ${ }^{20} \mathrm{It}$ may come as no surprise that the WIPO Internet treaties'TPM provisions impose no counterbalancing obligation on member states to preserve users' exercise of permitted acts on copyright works without the permission of the copyright holders, such as through fair use, fair dealing, and other long-established exceptions to copyright infringement. ${ }^{21}$ Member states may enact provisions to preserve exceptions to or limitations on copyright in the digital age, as long as they are not inconsistent with their obligations under the WIPO Internet treaties. ${ }^{22}$

The absence in the WIPO Internet treaties of obligations to copyright holders who benefit from TPMs, that is, to allow users to perform acts not requiring their authorization, did not preclude some jurisdictions from imposing counterbalancing obligations on copyright holders who benefit from TPMs. EU Directive 2001/ $29 / E C^{23}$ imposes obligations on its Member States to require copyright holders to make available to beneficiaries of certain exceptions or limitations to copyright (including reprographic copying and quotations used for teaching or scientific research purposes), ${ }^{24}$ the means of benefiting from those exceptions and limitations. ${ }^{25}$ However, the Member States' obligations apply to certain exceptions only, ${ }^{26}$ and are subject to an important caveat. The obligations do not apply to "works and other subject matter of copyright made available by contract under which members of the public may access them from a place and at a time individually chosen by them.' ${ }^{27}$ Excluding copyright holders from having to accommodate

18 See e.g., Canada Copyright Modernization Act (n 14) Preamble, which specifically refers to the need for Canada to coordinate its approach with other countries through the adoption of internationally recognized copyright norms. For many years, the US placed Canada and other countries on its Special 301 'Watch List' of countries that allegedly fail to enforce intellectual property rights (including copyright) at the proper level. See Office of the United States Trade Representarive (USTR) government's Special 301 'Watch List', online: <hteps:/ustr.gov/issue-areas/inrellectual-property/ Special-301> accessed 4 February 2017.

199 September 1886, 828 UNTS 221, art $20 . \quad 20$ ibid.

21 On how this void does not allow a balance between copyright holders and users, see, David Vaver, 'Copyright and the Internet: From Owner Rights and User Duties to User Rights and Owner Duties?' (2007) Case W Res L Rev 731.

22 See WCT (n 2) art 10, under which exceptions to copyright exclusive rights must meet three requirements (the 'three-step test'); agreed statement to art 10, ibid. See Chapter 2: 'Exceptions to copyright infringement and international obligations.'

23 EC, Directive 200I/29/EC of the European Parliament and of the Council of 22 May 2001 on the harmonisation of certain aspects of copyright and related rights in the information society, [2001] O], L $167 / 10$ [Directive 2001/29/EC].

24 ibid, art 6.4. The exceptions are: reprographic copying, quotations used for teaching or scientific research purposes, uses benefiting people with a disability and, at the option of Mernber States, private
copying: ibid.

25 ibid. $\quad 26$ ibid. 27 ibid, art 6.4 para 4. 
exceptions to copyright infringement, when their works are made available online, with no further distinction on how the works are made available, reflects the confusion between copyright works accessed through services (such as streaming), and copies of copyright works made available online and downloaded by users, as identified in Chapter $4 .{ }^{28}$ When users download a copy from the Internet, that copy allows them to exercise a level of autonomy similar to, if not greater than, the one they exercise with copies they obtain in the offline world. It should allow users to benefit from the same protection that Directive 2001/29/EC offers to copies of copyright works not made available 'on demand'. ${ }^{29}$ Overall, the copyright holders' obligations to accommodate users pursuant to Directive 2001/29/EC, as a counterbalance to the additional protection of TPMs conferred by the Directive, are limited. ${ }^{30}$

More than 20 years after the adoption of the WTPO Internet treaties, developments at the international level signal greater attention to the effects of TPMs on users' legitimate uses. The Marrakesh Treaty to Facilitate Access to Published Works for Persons Who Are Blind, Visually Impaired, or Otherwise Print Disabled [Marrakesh Treaty 2013] ${ }^{31}$ departs from the copyright-holder-centric approach of the WTPO Internet treaties by mandating each member state to ensure that TPMs implemented in its jurisdiction do not prevent beneficiaries from enjoying the exceptions to copyright infringement set out in the treaty. ${ }^{32}$ The Trans-Pacific Partnership [TPP] does not impose obligations on member states to ensure that users maintain the benefit of non-infringing uses of copyright works, but it sets parameters under which member states may provide limitations on and exceptions to TPMs. ${ }^{33}$

\section{Implementation of technological protection measures at national level}

The WIPO Internet treaties of 1996 gave rise to the implementation of different levels of legal protection by member states. ${ }^{34}$ With the entry into force of the Digital Millennium Copyright Act $[D M C A]^{35}$ in 1998, the US adopted one of the strongest TPM regimes. Preparatory works leading to the adoption of the

${ }^{28}$ See Chapter 4: 'Misconceptions about tangibility and intangibility in defining information products.'

29 I.c., the level of protection offered by Directive $200 I / 29 / E C$ (n 23) art 6.4, para 1 .

30 Zohar Efroni, Access-Right: The Future of Digital Copyright Law (New Yotk: Oxford University Press, 2011) at 367-80, analysing the TPM regime of Directive 2001/29/EC and how limited is the Member State obligation to accommodate the exercise of exceptions to copyright infringement.

${ }^{31} 27$ June 2013, online: chttp://www.wipo.int/treaties/en/text.jsp?file_id=301016> accessed 4 February 2017.

32 ibid art 7. $\quad 33 \operatorname{TPP}$ (n 17) art 18.68(4).

34 Giuseppe Mazziotti, EU Digital Copyright and the End-User (Berlin: Springer-Verlag, 2008) at 179-229, comparing the EU, selected Member States, and US implementation of TPMs pursuant to the WIPO Internet treaties (n 2); see also Efroni (n 30) at 348-80; see generally Geist, "The Case for Flexibility" (n 3).

39 Digital Millennium Copyrigbt Act, Pub L No 105-304, 112 Stat 2860 (1998), atnending 17 USC, including the introduction of $\$ \$$ 1201-1205 [DMCA]. 
$D M C A$ acknowledged that the $D M C A$ went beyond the minimum requirements of the WIPO Internet treaties, ${ }^{36}$ but that the threat posed by the digital environment to the relevant creative industries and electronic commerce required a strong level of protection. ${ }^{37}$ Directive 2001/29/EC $C^{38}$ imposed on EU Member States the implementation of a strong level of protection for TPMs ${ }^{39}$ tempered by a limited obligation to require copyright holders to make available to beneficiaries of certain exceptions to copyright infringement the means to benefit from those exceptions. ${ }^{40} \mathrm{~A}$ closer look at Directive 2001/29/EC reveals that the obligations imposed on Member States to accommodate exceptions to copyright infringement are limited, ${ }^{41}$ situating the EU among other regimes of TPMs that impose a high level of protection. ${ }^{42}$ Countries including Canada and Australia have enacted a high level of protection for technological measures comparable to the US. ${ }^{43}$ Countries offering a lower level of protection of technological measures include Japan, Switzerland, and New Zealand. ${ }^{44}$

The following overview highlights the detrimental effects that stronger regimes of TPMs have on copyright user rights, in particular in the US and the EU, given the political and economic importance of these jurisdictions, the size of their cultural and innovation industries, and their ability to influence the adoption of similar tegimes of protection through bilateral, regional, or multilateral trade agreements.

Stronger regimes of TPMs typically comprise two forms of prohibition. The first prohibits the trafficking of products or provision of services that allow the circumvention of a technological measure that controls access to a protected copyright work

36 US, House Judiciary Committe, WIPO Copyright Treaties Implementation and on-line Copyright Infringement Liability Limitation (HR Rep No 105-551) (1998) at 5, online: chttp:/www.gpo.gov/ fdsys/pkg/CRPT-105hrpt551/html/CRPT-105hrpe551-pt2,htm> accessed 4 February 2017 [US It ibid.

36 Directive 2001/29/EC (n 23). The Directive does not apply to the legal protection of computer programs: ibid Preamble, recital (50), art 1. The legal protection of computer programs is covered by programs, [2009] O], L 111 [Directive 2009/24/EC of 23 April 2009 on the Legal protection of computer

39 Directive 2001/29/EC (n 23), art 6.

40 See above in this section the discussion on the EU TPM regime imposing limited obligations on copyright holders to ensure users have the benefit of certain excepcions to copyright infringement.

42 Directive 2001/29/EC (n 23) art 6. See Mazziotti (n 34) at 184; Efroni (n 30) at 367-80. (Cth), ss $116 \mathrm{AK}-1$ l6AQ [Aust CA].

44 Federal Act on Copyright and Related Right (SWITZ), of 9 October 1992 art 39a; Copyright Act Aet 1994 (NZ), 1994/143, ss 226ff, in Pacific Partnership Arreement 5 226f, in particular s 226(D) (prior to amendments made by Transmational implementation of TPMs in Flexibility' (n 3) at 233 of TPMs in Japan, Switzerland, and New Zealand, see Geist, "The Case for 'Study on Copyright Limitations and ExP Standing Committee on Copyright and Related Rights, Kenneth D Crews (10 June 2015) at 287-88, 396, Libraries and Archives: Updated and Revised' by right/en/sccr_30/scer 30 2015) at 287-88, 396, online: <http://www.wipo.int/edocs/mdocs/copyand Exceptions']. 
('access controls') ${ }^{45}$ or that protects a right in a work ('copy controls'). ${ }^{46}$ The second prohibits the circumvention of effective access-control technological measures, ${ }^{47}$ and in some jurisdictions (e.g., EU), the prohibition extends to the circumvention of copy-control technological measures. ${ }^{48}$ The prohibitions apply to effective technological measures. ${ }^{49}$ The anti-trafficking prohibition often requires certain thresholds to be met to trigger infringement, for example, the degree to which the device or service is used to circumvent a technological measure relative to other non-infringing uses. ${ }^{50}$ In jurisdictions including the US and Canada, exemptions to the prohibition of the circumvention of access controls may apply from time to time to a certain class of persons or type of works if there is a likelihood of adverse effects on the ability to make non-infringing uses of a particular class of works. ${ }^{51}$ Various exceptions apply to the TPM prohibitions to address among others, law enforcement and interoperability issues. ${ }^{52}$

Beyond the online distribution of copyright works where copyright holders protect their works with various forms of technological measures, digital locks are also increasingly present in the world of physical objects, which primary purpose is nor to embody the copy of the copyright work (e.g., a DVD, a CD) but to serve broader functions, such as in the case of a game console, a car, or a tractor. Courts have enforced anti-trafficking prohibitions against chips that circumvent protections in game consoles, ${ }^{53}$ against software ('bot') to help video game users to advance game levels, ${ }^{54}$ against mechanisms allowing users to circumvent content-scrambling system (CSS) technology in DVDs and make copies

4517 USC $\$ 1201(a)(2)$ (2010) [USC]; Canada CA (n 43) s 41.1(b); Austl CA (n 43) ss 116AO-116A?.

46 USC (n 45) $\$ 1201$ (b)(1); Directive 2001/29/EC (n 23) art 6.2; Canada CA (n 43) s 41.1(b); Austl CA (n 43) ss 116AO-116AP.

17 USC (n 45) $\$ 1201(\mathrm{a})(1)(A)$; Directive 2001/29/EC (n 23) art 6.2; Canada CA (n 43) s 41.1(1) (a); Aust CA (n 43) s 116AN.

4 Directive 2001/29/EC (n 23) art 6.1.

9 USC (n 45) $\$ 91201$ (a)(1)(A), 1201(b)(1) 1201(a)(2); Directive 2001/29/EC (n 23) art 6.3; Canada CA (n 43) s 41 'technological protection measure.'

${ }^{50}$ USC (n 45) \$S 1201(a)(2), 1201(b)(1); Directive 2001/29/EC (n 23) art 6.2; Canada CA (n 43) s 41.1(1); Austl CA (n 43) s llGAN(1). In the EU, see Nintendo Co Lid $\nu$ PC Box SRL, C-355/12, [2014] (ECJ) at para 30, online: <http://euria.curopa.eu/juris/document/document. jsfedocid $=146686 \&$ doclang=EN> accessed 4 February 2017 [Nintendo], the EU Court of Justice (fourth Chamber) applying Directive 200I/29/EC (n 23) art 6.2, in light of recital 48 as imposing a requirement of proportionality on the legal protection of technological measures which "should not prohibit devices or activities which have a commercially significant purpose of use other than to eireumvent the technical protection.'

s1 USC (n 45) 1201 (a)(1)(c). See also Canada CA (n 43) s 41.21(2)(a).

32 USC (n 45) $\$ \$ 1201$ (d)-(j); Canada CA (n 43) ss 41.11-41.18;Austl CA (n 43) ss 116AN(2)-(9).

33 US v Reichert, 747 F (3d) 445 (6th Cir 2014), violation of USC (n 45) 91201 (a)(2)(A); Kabushiki Kaisha Sony Computer Entertainment Inc and Others $v$ Ball and Others, [2004] EWHC 1738, [2005] ECC 24; $R$ v Gilham (Christopher Paul), [2009] EWCA Crim 2293, [2010] ECDR 5i see also Nintendo (n 50 ) at para 28 , where the EU Court of Justice held that microchips in game consoles constituted technological measures that could be protected under Directive 2001/29/EC (n 23) art 6, even if the technological measures were not applied to the copies of the work or other subject matter of copyright per se, such as the DVD of a videogame.

54 MDY Industries v Blizzard Entertainment and Vivendi Games et al, 629 F (3d) 928 (9th Cir 2011) (upholding finding of violation of USC (n 45) \$ I201(a)(2)). 
of DVDs, ${ }^{55}$ against the link to a software that facilitated the circumvention of technological measures, ${ }^{56}$ and against cable filters and other devices that gain access to television signals. ${ }^{57}$ Courts have enforced prohibitions against the circumvention of access-control technological measures, for example, access controls on servers hosting videogames (only made available to authorized users), ${ }^{58}$ against circumvention technologies permitting the decryption of sofware securing video distribution on the Internet ${ }^{59}$ (to protect access-control software preventing streaming technology from being copied), ${ }^{60}$ as well as against the use of decryption software to gain access to the operating system of a major computer software and hardware provider. ${ }^{61}$

\section{Link between copyright infringement and contravention to technological protection measures}

Two of the most striking features of stronger TPM regimes are, first, the absence of a link between copyright infringement and the anti-circumvention prohibitions. ${ }^{62}$ Liability for circumventing access-control technological measures may arise independently of an infringement of copyright. ${ }^{63}$ As one commentator notes, the legal protection of technological measures is blind to the lawfulness of the use. ${ }^{64}$ TPMs do not parallel the existing exclusive rights of copyright holders, but rather endorse an indiscriminate lockout approach. ${ }^{65}$ The second striking feature of strong TPM

ss Realnetworks, Inc v DVD Copy Control Association, 641 F Supp (2d) 913 (ND Cal 2009), preliminary injunction granted based on likelihood of contravention of $\$ 1201(\mathrm{a})(2)$ and $\$ 1201(\mathrm{~b})$.

56 See Universal City Studios, Inc v Corley, $273 \mathrm{~F}$ (3d) 429 at 435 (2d Cir 2001), where defendant found to be in violation of USC (n 45) $\$ 1201$ (a)(2)(A).

57 CoxCom Inc v Chaffee, 536 F (3d) 101 (1st Cir 2008); Directv Inc v Carrillo, 227 Fed Appx 588 (9th Cir 2007).

50 Evony v Holland 2011 US Lexis 34700 (WD Pa) violation of USC (n 45) $\$ 1201$ (a)(1)(a).

59 Eyepartner Inc v Kor Media Group, 2013 US Lexis 98370 (SD Fla Dist Ct, interlocutory injunction granted for violation of USC (n 45) $\$ 1201$ (a)(1)(a).

${ }_{60}$ Stockwire Research Group Inc v Lebed, 577 F Supp (2d) 1262 (SD Fla 2008).

61 Apple Inc v Pystar Corp, 673 F Supp (2d) 931 (ND Cal 2009), preliminary judgment pursuant to which Psystar was found to be in contravention of USC (n 45) $\$ \$ 1201(\mathrm{a})(1), 1201(\mathrm{a})(2)$, and 1201 (b)(1); permanent injunction granted against defendant: Apple Inc v Pystar Corp, 673 F Supp (2d) 943 (ND Cal 2009); permanent injunction, summary judgment finding of absence of copyright misuse affirmed on appeal: Apple Inc v Psystar Corp, 658 F (3d) 1150 (9th Cir 2011).

62 USC (n 45) $\$ 1201$ (a)(1)(A); Directive 200I/29/EC (n 23) art 6.1; Canada CA (n 43) s 41.1(1) (a); Austl CA (n 43) s 11 GAN. See, however, Chamberlain Group, Ine v Skylink Techs, Inc, 381 F.(3d) 1178 (Fed Cir 2004) [Chamberlain] establishing a test linking the application of the TPM provisions to copyright infringement; see also Storage Technology Corp v Custom Hardware Engineering and Consulting Inc, $431 \mathrm{~F}$ (3d) 1374 (Fed Clr 2005); see however MDY Industria ע Blizzard Entertainment and Vivendi Games et al (n 54) not linking TPM provisions to copyright infringement as was done in Chamberlain.

63 USC (n 45) \$1201(a)(1)(A); Directive 2001/29/EC (n 23) art 6.1; Canada CA (n 43) s 41.1(1) (a); Aust CA (n 43) s 116AN.

64 Craig (n 3) at 192. On a review of the effects of TPMs blocking lawful uses of copyright works, including tesearch, fair use, see Electronic Fronticr Foundation, 'Unintended Consequences: Fifteen Years Under the DMCA' (March 2013), online: ehttps:/www.eff.org/document unintended-consequences-fifteen-years-under-dmeas.

65. Craig (n 3) at 192. 
regimes is that exceptions to copyright infringement are no defence against alleged violations of the TPM prohibitions. ${ }^{66}$ TPMs created a parallel universe with their own rules and exceptions, adding another layer of protection or 'para-copyright' to copyright holders' exclusive rights. ${ }^{67}$

In the EU, the statement that in stronger TPM regimes there is typically no link between the copyright infringement and the anti-circumvention provisions may need to be tempered in light of recent jurisprudential developments. In Nintendo Co Ltd v PC Box SRL [Nintendo], ${ }^{68}$ the EU Court of justice interpreted the legal protection offered by Directive 2001/29/E ${ }^{69}$ as applying 'only in the light of protecting that right holder against acts which require his authorisation. ${ }^{70}$ While Nintendo makes clear that the role of technological measures must be to prevent and block copyright infringement in order for them to be protected by law (therefore making a link between copyright infringement and the legal protection of technological measures), it is uncertain whether Nintendo could be interpreted as allowing users to circumvent a technological measure by self-help mechods for the purpose of an act for which the users would not notmally require authorization from the copyright holder. ${ }^{71}$ The Court stated that 'legal protection is granted only with regard to technological measures which pursue the objective of preventing or eliminating, as regards works, acts not authorised by the right holder of copyright, ${ }^{72}$ adding a proportionality requirement that the measures 'must not go beyond what is necessary for this purpose. ${ }^{73}$ It is one thing to say that the technological measure must be linked to preventing or eliminating non-authorized acts to receive legal protection. It is quite another to say that a technological measure that fully achieves that goal can be circumvented as self-help for the purpose of an act that does not require the authorization of the right holder. Nintendo needs to be interpreted in the contexr of the EU legal framework of TPMs as set out in Directive 2001/29/EC. ${ }^{74}$ Unlike other jurisdictions including the US and Canada, Directive 2001/29/EC prohibits the circumvention of copy controls, and not only the circumvention of access controls.

Countries granting a lower level of protection to technological measures (e.g., Japan, New Zealand, and Swizerland) typically link the liability for circumvention to an infringement of copyright. ${ }^{75}$ In doing so, jurisdictions linking liability

${ }^{66}$ See Universal City Studios, Inc v Corly (n 56); Universal City Studios, Inc v Reimerdes, 111 F Supp (2d) 294 (SDNY 2000); Apple Ine v Psystar Corporation, 673 F Supp (2d) 931 (ND Cal 2009), on appeal: Apple Ine v Pystar Corponation 658 F (3d) 1150 (9th Cit 2011); Realnetruorks, Inc v DVD Copy Control Association, 641 F Supp (2d) 913 (ND Cal 2009). Users are, however, allowed to perform acts covered by exceptions to copyright infringement because the circurnvention prohibitions do not ban the circumvention of 'copy controls': USC (n 45) $\$ 1201$ (a)(1)(A); Canada CA (n 43) s 41.1(1)(a); see discussion below in this section.

${ }^{67}$ Glynn S Lunney, Jr, "The Death of Copyright: Digital Technology, Private Copying and the Digital Millennium Copyright Act' (2001) $87 \mathrm{Va} \mathrm{L} \mathrm{Rev} 813$ at 839-40; see Efroni (n 30) at 348-67.

${ }_{6}$ Nintendo (n 50). ${ }_{69}$ Directive 2001/29/EC (n 23) art 6.

to Nintendo (n 50) at para $25 . \quad 71$ ibid. See also para $31 . \quad 72$ ibid at para 31.

${ }_{73}$ ibid. $\quad{ }_{74}$ Directive 2001/29/EC (n 23).

75 See 'WhPO Study on Copyright Limitations and Exceptions' (n 46); see Geist, 'The Case for Flexibility' (n 3). 
for circumvention to an infringement of copyright seek to offer greater protection for digital copyright works while promoting access to and lawful uses of copyright works.

The missing link in strong TPM regimes, that is, between circumvention and an infringement of copyright to trigger the application of the anti-circumvention provisions, combined with anti-trafficking provisions, shifted the paradigm in copyright law. Access controls and use controls are now merged under the helm of copyright holders, and included in copyright holder's ability to control and constrain the exercise of basic user property rights to the work and exceptions to copyright infringement. ${ }^{76}$

For supporters of strong TPM regimes, copyright has come of age with the aid of new technologies optimizing the protection of works. ${ }^{77}$ Strong TPM regimes are the confirmation that copyright holders have the right to control access to their copyright works. ${ }^{78}$ The proper balance lies in providing a sufficient level of protection that will promote the future creation of digital copyright works to be disseminated for the benefit of users and the public. ${ }^{79}$

Critics of strong TPM regimes argue that copyright underwent an important transformation from what it had been since the Statute of Anne: a limited exclusive right qualified by strong public interest underpinnings limiting the monopoly consequences of overly broad protection. ${ }^{\text {B0 }}$ For some commentators, TPMs brought on 'The Death of Copyright', 11 or were a 'A Riff on Fair Use'. ${ }^{82}$ Access controls were never part of the exclusive rights of copyright holders. ${ }^{83}$ Critics raise concerns about the effect of the legal protection of technological measures on access to copies of copyright works (which may include materials that are in the public domain), ${ }^{84}$ as well as the power the protection gives copyright holders to control uses of copyright works (amount of reading, viewing, and listening) that are traditionally outside the scope of copyright holders' exclusive rights. ${ }^{85}$

76 On the progtessive transformation of copyrighe toward an access tight, see generally Efroni (n 30).

77 Jane C Ginsburg, 'From Having Copies to Experiencing Works: The Development of an Access Right in U.S. Copyright Law' (2003) 50 J Copyright Society USA 113 [Ginsburg, 'From Having Copies to Experiencing Wortes"].

${ }_{78}$ Jane C Ginsburg, 'Can Copyright become User-Friendly? Review; Jessica Litman, Digital Copyright' (2001) 25 Colum JL \& Arts 71 at 75-76; Ginsburg, 'From Having Copies to Experiencing Works' (n 77) at 123. Ginsburg acknowledges troubling aspects of the implementation of the WIPO Internet treaties in the US through the DMCA: Jane Ginsburg, 'Copyright Legislation for the Digital Millennium' (1999) 23 Colum JL \& Arts 137 at 152-53.

79 For a copyright-holder-centric account of the goals of the $D M C A$ (n 35) as primarily implemented to protect copyright holders against online piracy, see US $v$ Reichert (n 53) at 448.

${ }^{80}$ Lunney (n 67) at 818. 11 ibid at 818-19. 82 Nimmer (n 14).

83 David Vaver, Intellectual Property Law Copyright, Patents, Trademarks, 2nd ed (Toronto: Irwin Law, 2011) at 199 [Vaver, Intellectual Property Law]; Craig (n 3) at 197; Severine Dusollier, Droit d'auteur et protection des oeuvres dans l'untivers numérigue, 2nd ed (Brussels: Larcier, 2007) at 384-85, $394-95$.

94 Craig (n 3) in particular at 195.

95 Jessica Litman, 'Lawful Personal Use' (2007) 85 Tex L Rev 1871 at 1872; Niva Elkin-Koren, 'Making Room for Consumers Under the DMCA' (2007) 22 BTLJ 1119 at 1143-44. 
In Canada, where the Supreme Court held in 2004 in CCH Canadian Ltd v Law Society of Upper Canada ${ }^{86}$ that exceptions to copyright infringement are user rights, ${ }^{87}$ the introduction thereafter of a strong TPM regime has cast doubt on the exact nature and scope of user rights in a digital environment. ${ }^{88}$ As discussed in Chapter 2, TPMs weaken arguments that exceptions to copyright infringement are rights and that they are mandatory. ${ }^{89}$ This weakening effect arguably extends beyond rights to digital works into other types of works. ${ }^{90}$ The cloud of uncertainty over the nature of exceptions to copyright infringement brought on by strong TPM regimes has rippling effects outside copyright law: it weakens even further the chance that users may build successful claims in contracts or consumer protection law against copyright holders who constrain their uses of copyright works.91

In the landmark US judgment Chamberlain Group, Inc v Skylink Techs [Chamberlain], ,2 $^{22}$ the Court of Appeals, Federal Circuit, bridged the act of circumvention or trafficking to copyright infringement by the requirement of a 'reasonable relationship' between the two:

A copyright owner seeking to impose liability on an accused circumventor must demonstrate a reasonable relationship between the circumvention at issue and a use relating to a property right for which the Copyright Act permits the copyright owner to withhold authorization-as well as notice that authorization was withheld. A copyright owner seeking to impose liability on an accused trafficker must demonstrate that the trafficker's device enables either copyright infringement or a prohibiced circumvention. ${ }^{93}$

The Court in Chamberlain arrived at these conclusions by contrasting the nature of TPM provisions, that is a liability regime, to copyright, that is creating property rights, ${ }^{94}$ making the scope of application of TPMs necessarily dependent on the transgression of the property rights of copyright holders. ${ }^{95}$ The judicial interpretation in Chamberlain of the US Copyright Act, which led to a 'reasonable relationship' requirement between the circumvention and copyright infringement, and enablement of copyright infringement or prohibited circumvention for attracting liability under the trafficking prohibitions, has not been consistently applied in subsequent judgments. ${ }^{96} \mathrm{~A}$ more literal interpretation of TPMs supports the creation of a para-copyright regime of protection strongly denounced in Chamberlain. ${ }^{97}$

\footnotetext{
2004 SCC $13 . \quad$. 66 See Chapter 2.

88 See Chapter 2: 'User rights or privileges?'

89 ibid. Pascale Chapdelaine, 'The Ambiguous Nature of Copyrighe Users' Rights' (2013) 26 IPJ I

at 37-43; see Chapter 2: "May exceptions to copyright infringement be waived by contract?'

${ }_{90}$ Pascale Chapdelaine, 'The Ambiguous Nature of Copyright Users' Rights' (2013) 26 IPJ 1 at 37-43; see Chapter 2: 'May exceptions to copyright infringement be waived by contract?'

91 See Chapter 3. $\quad 92$ Chamberlain (n 62). ${ }_{93}$ ibid at 1204.

94 ibid at $1192 . \quad 95$ ibid at 1204.

96. See MDY Industries v Blizzard Entertainment and Vivendi Games et al (n 54).

97 Chamberlain (n 62) at 1999-2001.
} 


\section{Prohibition against circumvention of access controls and not copy controls}

For some courts and commentators, and as evidenced in preparatory works leading to the enactment of TPM provisions under the US DMCA, the prohibition against the circumvention of access controls and not copy controls (unlike the anti-trafficking provisions which apply to access controls and copy controls) reflects a balance between the competing interests of copyright holders on the one hand, and those of copyright users and the public domain on the other. ${ }^{98}$ The premise behind punishing circumvention of access controls but not copy controls is that copyright holders should legitimately control the lawful access to their works. Once this lawful access is granted, users should be able to make any lawful use of the copyright work, including uses that do not require the consent of copyright holders (such as fair use, fair dealing, or non-commercial user-generated content). Users should not be liable for infringement if they circumvent copy controls to achieve that goal.

At first sight, the prohibition of the circumvention of access controls, but not copy controls, seems to strike a balance between the interests of copyright holders and those of copyright users by allowing users to circumvent copy controls for lawful uses of the copyright work. ${ }^{99}$ While copyright law may not have granted access controls to copyright holders in the past, the law did not allow users to access copies unlawfully either. Unlawful access to copies was addressed in another legal sphere: the theft of a chattel (e.g., copy of a book, music CD), bypassing library loan privileges, etc. Following that line of reasoning, the prohibition of circumvention of access controls was justified given the perceived lack of adequate legal protection against such acts: circumventions can take place without any taking or stealing, hence the lack of an actionable wrong. ${ }^{100}$

The appeal of the balance that TPMs seek to strike between diverging interests by distinguishing circumvention of access controls from that of copy controls for the purpose of infringement may be short lived. ${ }^{101}$ In those jurisdictions prohibiting the circumvention of access controls, but not copy controls, while there is no infringement for circumventing copy controls for lawful uses, the onus is entirely placed on the users' ability to circumvent the technological measures with no counterpart obligation on the part of copyright holders to facilitate such uses. Makers of circumventing devices, distributors, service providers, and others are

9a US, House Judiciary Committee (n 36) 'fair use in the digital environment'; Universal City Studios, Inc v Reimendes (n 66); United States of America v Elcom Ltd, 203 F Supp (2d) 1111 at $1138-$ 1141 (ND Cal 2002).

99 See e.g., Canada CA (n 43) s $41.1(1)$.

100 Vaver, Intellectual Property Law (n 83) at 197-98; Jeremy F de Beer, 'Locks \& Levies' (2006) 84 Denv UL Rev 143 at $152-55$.

101 Efroni (n 30) at 355-56, discussing how the distinction between access controls and copycontrol technological measures is murky and how it might collapse. 
also liable for infringement, ${ }^{102}$ which diminishes even further consumers' and other users' ability to circumvent copy controls, in spite of the lawfulness of their intended uses.

While advocates of TPMs will argue that this is the only effective means to counterbalance the scourge of digital piracy, a legal framework that allows the combination of unfettered powers of access controls with exclusive copyright, and that does not place the onus on copyright holders to allow lawful uses of their works by 'lifting' copy controls, tilts the balance toward copyright holders even further and imposes the burden of countering piracy on lawful copyright users, by constraining their uses of copyright works. Courts have acknowledged that a strong TPM regime effectively favours copyright holders to the detriment of users and the public domain. ${ }^{103}$

Even lower levels of protection of technological measures linking liability for circumvention to copyright infringement do not on their own adequately balance the interests of copyright holders with the legitimate interests of users. The onus remains on users to find adequate circumvention tools to make lawful uses of protected copyright works. Something more is required than linking liability for circumvention to copyright infringement, if one is to take digital copyright user rights seriously.

\section{Setting requirements for technological protection measures}

The biggest flaw with strong TPM regimes is that they give almost carte blanche as to how copyright holders may protect their copyright works. Without carefully mapping TPMs with the purpose, function, scope of copyright, its limitations and exceptions, technological measures protected by such strong TPM regimes effectively allow copyright holders to 'write their own intellectual property statute in computer code. ${ }^{104}$ How courts have enforced stronger regimes of TPMs in conjunction with contract terms, allowing the latter to effectively waive fair use or other exceptions to copyright infringement, ${ }^{105}$ confirms that view. In jurisdictions with stronger TPM regimes, there is little hope that judicial interpretation alone could properly balance competing interests. ${ }^{106} \mathrm{~A}$ natural inclination of courts seems to be to view TPMs as embedding the required balance between compering interests, even in jurisdictions with stronger TPM regimes. ${ }^{107}$

102 See e.g., USC (n 45) $\$ \$ 1201$ (a)(2), 1201(b)(1); Dinective 2001/29/EC (n 23) arts 6(2)-(3), 8(2); Canada $C A$ (n 43) s 41.1(1)(b)-(c); Austl CA (n 43) ss 116 (AO), 116(AP).

103 See e.g., Realnetworks, Inc v DVD Copy Control Association 641 F Supp 2d 913 (USDC ND Cal., 2009) 943-44,

104 Dan L Burk \& Julie E Cohen, 'Fair Use Infrastructure for Rights Management Systems' (2001)

15 Harv JL \& Tech 41 at 51. See also: Giuseppe Mazziotti (n 34) at 227.

${ }_{105}$ See e.g., Davidson \& Associates Inc, et al y Internet Gateway, 334 F Supp (2d) 1164 at 1180-81 (ED Mo 2004); Eyepartner Inc $v$ Kor Media Group LLC et al, 2013 US Lexis 98370 at 10-11 (SD Fla).

106 See discussion above on Chamberlain (n 62) and how the court's interpretation of the DMCA (n 35) as linking the prohibition of circumvention to infringernent has not been consistently followed.

107 See e.g., Universal City Studios, Ine v Reimerdes (n 66); US v Elcom (n 98). See, however, Chamberlain (n 62). 
There is generally no requirement that to receive legal protection, technological measures need to embed a mechanism that facilitates the exercise of fair dealing, fair use, or other exceptions to copyright infringement. Without such a requirement, the view that TPMs properly balance the competing interests of right holders, users, and the public domain is not convincing at best. Imposing requirements on technological measures that accord with the main objectives of copyright law (including exceptions to copyright infringement) ties in to the broader discussion on the extent to which contracts may or should alter the exercise of exceptions to copyright infringement. ${ }^{108}$ As part of that discussion, arguing that the benefit of exceptions to copyright infringement may not be compromised through private ordering is generally based on the idea that (some) exceptions fulfil an important public interest function. ${ }^{109}$

By setting requirements on the design of technological measures to allow the exercise of user rights or exceptions to copyright infringement, the law would aim to recalibrate the effects of TPMs toward a greater recognition of the public and user interests embedded within copyright law. ${ }^{110}$ As required by Directive 2001/29/ $E C,{ }^{111}$ European jurisdictions, including France and Belgium, impose a requirement on right holders protecting their works with TPMs to take adequate measures to allow users to benefit from certain exceptions to copyright infringement. ${ }^{112}$ Daniel Burk and Julie Cohen proposed a 'mixed fair use infrastructure' that could help achieve that goal. ${ }^{113}$ The law could require that the architecture of technological measures embed a minimum automatic level of fair use or fair dealing of copyright works, based on customary norms and practice. ${ }^{114}$ For instance, a music provider could allow a limited number of copies of a musical recording for noncommercial use. The US Copyright Act already imposes similar requirements on the structure of some technological measures. ${ }^{115}$ For uses beyond a pre-set allowance of exercises of fair use, a trusted third-party intermediary would be put in place to manage access keys. ${ }^{116}$ Copyright holders failing to make the necessary key deposits would not benefit from the legal protection of their technological measures, thereby effectively giving way to a 'right to hack' as a substitute for access through

\footnotetext{
108 See Chapter 2: 'User rights or privileges?' and 'May exceptions to copyright infringement be waived by contract?'

109 ibid. See also Chapter 8: 'Adjusting the balance.'

110 Burk \& Cohen (n 104) discussing various legal and technologieal designs that can be pur in place; Stephan Bechtold, 'The Present and Future of Digital Rights Management' in E Becker' 'et al, eds, Digital Rights Management (Berlin: Springer-Verlag, 2003) at 597-654, discussing the flexibility of digital rights management including technological measures; Mazziont (n 34) at 215f, on how such requirements are feasible in light of ongoing digital rights management technology developments.

i11 Directive 2001/29/EC (n 23) art 6.4.

${ }^{112}$ Art L 331-7 CPI (France). See also Wetboek van Economische Recht/Code de Droit Economigue (Belgium), art X $291 \$ 2$. See Chapter 3: 'User claims and temedies in copyright law.'

113 Burk \& Cohen (n 104) at 65E. 114 ibid at 65.

115 ibid at 58, citing the Audio Home Recording Act, 17 USC $\$ 1002$ (2001) regarding digital audio tape recordings and allowing the production of only one generation of perfect copies, and 17 USC $\$ 1201(\mathrm{k})(2)$ (2001), imposing certain requirement on copy-control rechnologies for videocassette recorders to allow time-shifting of broadcasts and cable television programming.

116 ibid at 65-67.
} 
the escrowed access keys. ${ }^{117}$ Prohibitions on the manufacture and distribution of circumvention technologies would need to be adapted accordingly. ${ }^{118}$

Proposals to introduce an exception of fair circumvention of technological measures are another way to rectify the imbalance TPMs brought in favour of right holders. ${ }^{119} \mathrm{~A}$ requirement that technological measures facilitate the exercise of exceptions to copyright infringement, such as the 'mixed fair use infrastructure' proposed by Burk and Cohen, would incorporate the fair circumvention exception, ${ }^{120}$ and would be even more beneficial to copyright users as it would place the onus on copyright holders to facilitate users' fair' dealing, fair use, or other exceptions to copyright infringement.

\section{The constitutionality of technological protection measures}

TPMs raise issues of balance of powers outside the confines of copyright law. In some jurisdictions including the US, the constitutionality of TPMs is questioned. ${ }^{121}$ The constitutionality of TPMs has three main themes. First, TPMs may exceed the legislative power and jurisdiction of the constitutional clatuse that vests in the relevant legislative authority (e.g., Parliament, Congress) the power to confer exclusive rights to copyright holders for their works. ${ }^{122}$ Based on that line of argument, TPMs are either unconstitutional because (i) they are unrelated to the purpose for which copyright was created ${ }^{123}$ or (ii) they spill over powers that the relevant constitution confers to other jurisdictions (e.g., province or state), such as regulating the sphere of traditional property rights, contracts, or consumer protection. ${ }^{124}$ In other words, merging the sphere of access control and use control over the physical copy of works with the sphere of control over the intangible intellectual property in the work would transgress the separation of powers conferred by the relevant constitution. Second, TPMs, in particular anti-trafficking provisions, may violate free speech or freedom of expression by limiting the expression embedded in the prohibited software code. ${ }^{125}$ Anti-circumvention provisions may also

117 ibid at 66. See also Mazziotti (n 34) at 220, proposing that TPMs that fail to allow the exercise of exceptions to copyright infringement should not receive legal procection.

118 Burk \& Cohen (n 104) at 66; Mazziotti (n 34) at 220.

119 Samuelson (n 14) at 543-46; Mazziotti (n 34) at 220-24.

120 I.e., limiting the protection of technological measures that are user friendly implies that users can circumvent technological measures that do not comply with user-friendly requirements.

121 On the constitutionality of TPMs in the US, see generally Julie E Cohen, 'Copyright arnd the Jurisprudence of Self-Help' (1998) 13 BTLJ 1089 at 1140-42. In Canada, see Jeremy G de Beer, 'Constitutional Jurisdiction over Paracopyright Laws' in M Geist, ed, In the Public Interest: The Future of Canadian Copyright Law (Toronto: Irwin Law, 2005) 89 [de Beer, 'Constitutional Jurisdiction'].

t21 Sec e.g., US Constitution, Art I, s 8; Canada Constitution Act, 1867 (UK), 30831 Vict, c 3, s 91 , para 23.

${ }_{123}$ See e.g., US $v$ Elcom (n 98) at 1137-42, where the court assessed the constitutionality of TPMs by determining whether TPMs are 'not fundamentally inconsistent' with the purpose of copyright. In Canada, the test is whether TPMs fall, 'in pith and substance' within the copyright clause conferring power to Parliament; see de Becer (n 121) at 92-I12.

124 See de Beer (n 121) at 99-100.

129 See Universal City Studios, Inc $v$ Corley (n 56): finding that the TPMs under the US Copyright Act were not unconstitutional on the ground thit the effect of the prohibition was content neutral on 
violate free speech by blocking access to protected and unprotected works and by restricting the exercise of fair use, on the basis that fair use should be conferred constitutional status as a vehicle enabling free speech through the limits it sets on the scope of copyright. ${ }^{126}$ Third, TPMs may violate constitutional protections of due process by being too broad or vague. ${ }^{27}$ On several occasions in the US, courts have rejected arguments challenging the constitutionality of TPMs. ${ }^{128}$

A closer look at stronger TPM regimes in various countries reveals the weakness of arguments that they allow an adequate balance between various competing interests. TPM regimes have been implemented predominantly with the interests of copyright holders in mind. By now, more than two decades following the signature of WTPO Internet treaties, stronger TPM regimes ought to be recalibrated, benefiting from a more refined understanding of the effects of the digital environment on the creation and dissemination of copyright works, as well as the effects of digital locks' infrastructures which espouse rather than disturb copyright law's public interest underpinnings.

\section{From Immaterial Works to Physical Objects}

Initially, the focus of attention leading up to the adoption of the TPM provisions at international and national levels was on copyright works made available online. The TPM provisions in the WIPO Internet treaties of 1996 incorporate one of the main objectives of the digital agenda, which was to provide adequate legal safeguards to encourage authors and copyright holders to make their works available online. ${ }^{129}$ In the US, preparatory works leading to the entry into force of the DMCA TPM provisions in 1998 refer mainly if not exclusively to the promotion of electronic commerce and the online distribution of copies of copyright works. ${ }^{130}$

owners' speech and did not burden substantially more speech than necessary to further government's interest. See also Efroni (n 30) at 359.

126 Universal City Studios, Ine v Corley (n 56) at 458-59: the court not having to decide on the constitutionality of TPMs restraining fair use, but nevertheless rejecting the argument that fair use enjoyed constitutional status. See Neil Weinstock Netanel, 'First Amendment Constraints on Copyright After Golan v. Holder' (2013) 60 UClA L Rev 1082 at 1113-20.

127 See US y Elcom (n 98) at 1122-25, the US district court (ND Cal) rejecting the argumentuthat USC (n 45) $\$ 1201$ (b) was unconstitutional and against the fifth amendment because " $[\mathrm{t}] \mathrm{he}$ law, as written, allows a person to conform his or her conduct to a comprehensible standard and is thus not unconstitutionally vague.' ibid at 1125 .

${ }^{128}$ See Universal City Studios, Inc v Corloy (n 56); US v Elcom Ltd (n 98); Universal City Studios, Ine v Reimerdes (n 66); 321 Studios v Metro Goldwyn Mayer Studios, Inc, 307 F Supp (2d) 1085 (ND Cal 2004).

129 See above: 'International obligations.'

130 See Senate Judiciary Committee, S Rep No 105-190 (1998) at 1-2, online: <http://digitallaw-online.info/misc/SRep105-190.pdf accessed 4 February 2017: "The Digital Millennium Copyright Act of 1998 is designed to facilitate the tobust development and world-wide expansion of electronic commerce, communications, research, development, and education in the digital age." See HR Rep No 105-551 (1998), online: http://www.gpo.gov/fdsys/pkg/CRPT-105hrpt551/html/ 
While the enactment of TPMs led to intense debate in several jurisdictions, ${ }^{131}$ focusing the attention on online immaterial copyright works likely facilitated their adoption. As discussed in previous chapters, the property rights of users in copies of copyright works are more easily overshadowed in the online world by the application of the exclusive rights of copyright holders. ${ }^{132}$ At the same time, the minimization of underlying property rights of users and of exceptions to copyright infringement through the adoption of TPMs reflects a phenomenon similar to the difficulty of defining online copies of copyright works as goods ${ }^{133}$ or to declaring that copyright exhaustion cannot apply to digital copies. ${ }^{134}$ In all of these cases, the threats of the online world, with its pirates and instantaneous worldwide dissemination of works, provided a fertile ground for downplaying the significance of copyright users' rights and broader public policy interests in the equation. ${ }^{135}$

Technological measures are now reaching far beyond the online world of copyright works and are frequently used and applied to physical objects not readily associated with copyright works: game consoles, ${ }^{136}$ cellphones, ${ }^{137}$ coffee machines, garage door locks, ${ }^{138}$ printer toner cartridges, ${ }^{139}$ coupons, ${ }^{140}$ cars, and farming equipment all form a disparate ensemble of chattels subject to TPMs. Although there might have been early indicators that courts might be more reluctant to enforce TPMs when they relate to digital locks embedded in chattels than when they relate to copyright works distributed online, ${ }^{141}$ recent developments show that courts are willing to enforce digital locks in chattels the function of which is not solely to embody a copyright work, as witnessed by cases in the EU and in the US applying TPM provisions to digital locks embedded in game consoles. ${ }^{142}$

CRPT-105hrpt551-pt2.htm accessed 4 February 2017: 'Purpose and summary, "Promoting electronic commerce,' and 'Understanding the nexus between electronic commerce and intellectual property.'

131 See above: 'Implementation of technological protection measures at the national level.'

132 See Chapters 1, 4, and $5 . \quad 133$ See Chapter $4 . \quad 134$ See Chapter 5.

135 On the rhetoric and metaphors utilized to secure greater copyright protection, see William Patry, Mont Panic and the Copyright War (New York: Oxford University Press, 2009) at 139-70. See US $\nu$ Reichert (n 53) at 448 , interpreting more than 15 years after its adoption the main purpose of the US DMCA TPM provisions to be the strengthening of copyright holders' rights against online piracy.

136 Courts have recognized that TPMs protect technological measures in game consoles. See: Sony Computer Entertainment America, Inc v Divineo, Inc, 457 F Supp (2d) 957 (ND Cal 2006); Sony Computer Entertatnment America v Hotz, 2011 WL 347137 (ND Cal); US v Reichert (n 53); Sony Computer Enmt'Am, Inc $v$ Gamemasters, 87 F Supp (2d) 976 at 987 (ND Cal 1999); Nintendo (n 50 ).

135 See TracFone Wireless, Inc v GSM Group, Inc, 555 F Supp (2d) 1331 (SD Fla 2008): the court finding no violation of US copyright TPM ptovisions.

138 Chamberlain (n 62) involved a technological measure inserted in an electronic garage door. The Court held that the defendant had not breached the USC (n 45) TPM provisions.

139 Lamark Int'h Inc $\nu$ Static Control Component, Inc, 387 F (3d) 522 (Gth Cir 2003) [Lexmark] dealt with microchips in toner cartridges. The Court denied the plaintiffs claims under USC (n 45) TPM provisions.

140 Coupons Inc v Stottlemire, 588 F Supp (2d) 1069 (ND Cal 2008) where the court held that registry keys downloaded to computers to limit the number of coupons issued to the public were technological measures protected under USC (n 45).

141 Elkin-Koren (n 85) at 1132-37, citing Chamberlain (n 62) and Lexmark (n 139) as examples.

142 See e.g., US v Reichert (n 53); Kabushiki Kaisha Sony Computer Entertainment Inc and Others $v$ Ball and Others (n 53); $R \nu$ Gilham (Christopher Paul) (n 53); see also Nintendo (n 50). 
The enforcement of TPM provisions in relation to digital locks embedded in physical objects magnifies the regulatory design deficiencies denounced when TPMs were initially adopted and enacted in various jurisdictions. ${ }^{143}$ First, a violation for circumventing access controls (independently of copyright infringement), where the technological measure is ancillary to a physical object, the primary function of which is not to embody a copyright work (e.g., a car or tractor), is strikingly beyond the scope and objectives of copyright protection, even more so than when the digital lock applies solely to a copyright work (e.g., an e-book or a film). ${ }^{144}$ Here the user would seek to circumvent a technological measure (protecting a software embedded in the chattel) to perform acts completely unrelated to a copyright work: repair a car, reset safety controls in the garage door, etc. The interaction with the copyright work (i.e., the software to which the digital lock applies) would be ancillary to the main underlying goal behind the circumvention. In that scenario, one might argue that the circumvention would be lawful because the technological measure would fail to be an 'effective technological measure' as required to merit the protection of TPM provisions. To be 'effective' a technological measure must pertain to a protected work and hence a technological measure controlling access beyond the copyright work would not receive protection under the TPM provisions. ${ }^{145}$ The counterargument is that the technological measure does protect a copyright work (i.e., the software) and is therefore an 'effective technological measure', making any practical access constraints beyond that irrelevant. The statutory language found in strong TPM regimes would support the far-reaching effects of technological measures beyond protecting the tuse of copyright works per se, as evidenced by recent case law on game consoles. ${ }^{146}$ The disproportionate encroachment of digital locks as enforced through TPMs on the prima facie open-ended privileges and powers of personal property owners is even more striking with a chattel where the copyright work it embodies is an ancillary portion of the chattel (e.g., a software chip in a tractor) than with a chattel the essential function of which is to embody the copyright work (e.g., a CD).

Second, arguments that TPMs are unconstitutional based on the legislative authority exceeding conferred powers and jurisdiction ${ }^{147}$ may be even stronger when digital locks, protected by TPM provisions, are embedded in chattels such as cars, farming equipment, and other objects not even remotely associated with copyright. In such cases, arguments that TPMs regulate traditional property and civil rights or extend beyond the jurisdiction of copyright protection become even more cogent when the TPM provisions impact the use and enjoyment of chartels level.'

143 See discussion above: 'Implementation of technological protection measures at the national 144 ibid.

145 ibid. See Lexmark (n 139) where the Court applied a similar reasoning, holding that a technological measure was not effective and therefore did not mandate protection under the $D M C A$ (n 35$)$, because it restrained access to computer code that was not protected under the USC (n 45).

146 See e.g., US v Reichert (n 53); Kabushiki Katsha Sony Computer Entertainment Inc and Others $v$ Ball and Otbers (n 53); $R v$ Gilham (Christopher Paul) (n 53); see also Nintendo (n 50).

147 See discussion above: "The constitutionality of technological protection measures." 
where the main function is not to embody copyright works, for example, tractors, refrigerators, and printer cartridges, than when the TPMs seek to protect the online distribution of musical recordings or e-books.

Third, the use of digital locks with copyright works (software) ancillary to chattels where the main function is not to embody a copyright work may raise anti-competition issues; for example, tied selling and control of the end-to-end distribution chain of related products. Anti-competition issues are even more likely in such situations than with technological measures that apply solely to copies of copyright works. In Chamberlain, the US Court of Appeals for the Federal Circuit discussed how a literal interpretation of TPMs would favour anti-competitive behaviour. ${ }^{148}$ Arguments that the use of digital locks amount to anti-competitive behaviour or copyright misuse have been made, often unsuccessfully. ${ }^{149}$ Given the explicit powers and privileges that TPMs confer on copyright holders, proving that their use leads to anti-competitive practices or copyright misuse is an uphill battle. ${ }^{150}$ The argument that the deployment of digital locks amounts to a misuse of rights is difficult to support when TPM regimes endorse the far-reaching effects of digital locks.

Fourth, the lack of notification of digital locks in products and the lack of a clear legal obligation to do so are even more problematic when digital locks protect a copyright work (software) ancillary to a chattel. In other words, the case for the users' right to be notified of the presence of digital locks is even stronger when users are less likely to expect the presence of digital locks in the personal property they own or possess. ${ }^{151}$

Last, the increasingly pervasive intrusion of digital locks in the world of chattels unrelated to copyright works may, in some jurisdictions, encourage review mechanisms that lead to exempting specific works, objects, and uses from the application of TPMs. ${ }^{152}$ More than half of the current exemptions to circumvention prohibitions under the US Copyright Act concern physical objects that are not commonly associated with copyright works. ${ }^{153}$ An ever-growing list of exemptions to the application of TPMs is less than desirable from a regulatory design perspective. It may signal too broad protection of TPMs. A long list of exemptions to TPM prohibitions would make their application increasingly complex and uncertain, adding to the already convoluted regulatory design layers of TPMs. A growing list of exemptions may also provide compelling evidence

119 See Chamberlain (n 62) at 1201.

149 See e.g., Apple Inc v Pystar Corp, 658 F (3d) 1150 (9th Cir 2011); Davidson \& Associates Inc v Internet Gateway Inc, 334 F Supp (2d) 1164 (ED Mo 2004). See Mazziotti (n 34) at 190-93, discussing anti-competitive daims against Apple's digital rights management (DRM) system and the interaction between TPMs and competition law.

150 ibid.

151 See Chapter 3: 'Restricted uses that fall within the exclusive rights of copyright holders and are permitted by law under certain conditions.'

152 See c.g., USC (n 45) $\$ 1201$ (a)(1)(c). See also Canada CA (n 43) s 41.21(2)(a).

153 Exemption to Prohibition on Circumvention of Copyright Protection Systems for Access Control Technologies, 80:208 Fed Reg 65944 (2015). 
of the need for legislative reform or may trigger jurisprudential developments that could limit the scope of TPMs, as calls for consultation by the US Copyright Office suggest. ${ }^{154}$

\section{The Shift from Possessing Copyright Works to Experiencing Them Through Services}

Parallel to the increased presence of TPMs in the world of physical objects beyond traditional copyright works (e.g., literary works, musical recordings, films) and their physical embodiments (e.g., books, music CDs, film DVDs), the shift from possessing individualized copies of copyright works to experiencing works through online services is a further manifestation of the prominent role of technological measures in digital copyright works. In an online service environment, technological measures are the backbone that defines the service offering and without which it could not exist. ${ }^{155}$ Digital copyright work service offerings, enabled through technological measures and TPMs, further distance users from the copyright work. In a service environment, the remoteness of the user from the copyright work changes their interaction with technological measures. Users of digital copyright services have lower expectations vis-d-vis how they can use the work and, as a consequence, are less likely to view the technological measure as interfering with how they experience the copyright work. In a service environment, the abdication of prima facie unlimited powers and privileges of copyright users to copies of copyright works for the benefit and control of copyright holders is now complete, and technological measures, as enforced by TPMs, are responsible for that to a great degree.

Some jurisdictions explicitly regulate technological measures applying to online copyright services differently from other technological measures. In relation to such services, EU Directive 2001/29/EC does not require Member States to take adequate legal measures for the regulation of TPMs to allow users to exercise the exceptions to copyright infringement specified in the Directive, as it does with respect to other technological measures that are not applied to online services. ${ }^{156}$ The exclusion in EU Directive 2001/29/EC is particularly problematic as it fails to distinguish online copyright services from copies of copyright works downloaded

154 Section 1201 Study: Notice and Request for Public Comment, 80:249 Fed Reg 81369 (2015). Areas the study hopes to address include the current permanent exemptions to the application of TPMs under the US Copyright Act, i.e., questioning the raison d'etre of existing caregories and whether other permanent categories of exemption should be established.

15s See e.g., the technological measures considered in: Evony v Holland (n 58); Stockwire Research Group Ine v Lebed (n 60).

156 EU Directive 2001/29/EC (n 23) art 6(4) para 4: "The provisions of the first and second subparagraphs shall not apply to wotks or other subject-matter made available to the public on agreed contractual terms in such a way that members of the public may access them from a place and at a time individually chosen by them.' See also Efroni (n 30) at 377-78. 
online. ${ }^{157}$ The indiscriminate and unfettered application of TPMs makes the abnegation of copyright users' rights in the environment of online on-demand services unequivocal.

\section{A Silver Lining for Copyright Users?}

The progressive intrusion and enforcement of digital locks in the world of physical objects will either provide a silver lining to users by triggering favourable legal reform, or will trivialize their rights even further.

While the disregard for copyright user property rights may have started when the application of TPMs focused on the online distribution of copyright works, the increased presence of digital locks and enforcement of TPMs on physical objects make the disproportionality between the protection of the property rights of copyright holders and disregard for the property rights of users even more striking.

The application of TPMs to digital locks embedded in chattels that serve a broader function than to embody the copy of a copyright work (e.g., cars, tractors, printer cartridges) is receiving public attention. ${ }^{150}$ As the application of TPMs to such chattels magnifies the defects of stronger regimes of TPM protection identified in the early days of TPMs, ${ }^{159}$ the application of TPMs to objects not typically associated with copyright works may be the silver lining for the future of copyright user rights. Such application may create the impetus for legal reform that will impose further limitations on the application of TPMs. Maintaining the status quo would confirm the strength of copyright holders' rights. Paradoxically however, adding more exceptions of the application of TPMs in the world of physical objects not typically associated with copyright works would further reinforce the legitimacy of the application of TPMs to traditional forms of embodiment of digital copyright works (CDs, DVDs, etc.).

157 EU Directive 2001/29/EC (n 23) art 6(4) para 4. See discussion in Chapter 4: 'The trouble with the requirement of a physical object to distinguish goods from services: misconceptions about tangibility and intangibility.'

158 Kyle Wiens, 'Forger the Cellphone Fighr-We Should be Allowed to Unlock Everything We Own,' Wiredcom (18 March 2013), online; ehttp:/www.wired.com/2013/03/you-dont-own-yourcellphones-or-your-cars/s accessed 4 February 2017; Dayna J Sondervan, 'Can Farmers Hack Tractor Software? Copyright Office Will Decide', Growing Georgia (5 May 2015), online: <http://growinggeorgia.com/features/2015/05/can-farmers-hack-tractor-software-copyright-office-will-decide/s accessed 4 February 2017.

159 See above: 'From immaterial works to physical objects.' 